\title{
Potansiyel Bir Karşı-Hegemonya Alanı Oluşturma Aracı Olarak Devasa Çok Oyunculu Çevrimiçi Oyunlar ${ }^{1}$
}

\author{
Tülin Sepetci \\ Dr. Öğr. Üyesi \\ Bolu Abant İzzet Baysal Üniversitesi İletişim Fakültesi \\ tulinsepetci@ibu.edu.tr \\ ORCID: 0000-0003-2584-4333
}

\section{Abstract \\ Massively Multiplayer Online Games as a Potential Means of Building Counter-Hegemonic Spheres}

This study aims to reveal whether massive multi-player online games (MMOG) are effective in creating a new field of resistance and counter-hegemony while questioning whether games make players passive and apolitical individuals. To this end, whether online games encourage players to organize, develop their cultural practices, create their own spaces of resistance and counter-hegemony, and allows them to take a specific political stance were analyzed through those who played MMOG in the study. As a method, an online questionnaire is conducted with 493 people, and the data obtained were evaluated under four factors. According to the findings of the statistical analysis, MMOGs encourage players (1) to develop their cultural practices (identification with the group); (2) to coexist within game groups based on rules (identification with the game); (3) to organize among themselves (social interaction), (4) to show critical, intellectual, strategic attitudes and behaviors; (5) to demonstrate their social, cultural and political stance (interaction between the game and the world); and lastly, through active virtual in-game communities, (6) to encourage the players as active subjects to engage in movements aimed at creating a new resistance and counter-hegemony (offline activism). However, players who play MMOGs do not engage in any activity unless there is an

1 Bu makale, yazarın Akdeniz Üniversitesi Sosyal Bilimler Enstitüsü'nde hazırladığı "Dijital Oyunlar, Dijital Oyuncular: Karşı Hegemonya Pratikleri ve Sosyal Etkileşim" başlıklı doktora tezinden üretilmiştir.

DOI:10.16878/gsuilet.957432 
interference in the "space" that they see it as their public space. Consequently, being in a passive state as long as players are not intervened can be considered as a weakening factor in the context of resistance movements and counter-hegemony.

keywords: Digital games, hegemony, counter-hegemony, massively multiplayer online games, online activism

\section{Résumé}

\section{Jeux en ligne massivement multijoueur comme moyen potentiel de construction de sphères contre-hégémoniques}

Cette étude, qui vise à révéler si les jeux en ligne massivement multijoueur sont efficaces pour créer un nouveau champ de résistance et de contre-hégémonie, questionne si les jeux rendent les joueurs des individus passifs et apolitiques. L'étude fait recours aux joueurs eux-mêmes afin de savoir si les jeux en ligne les encouragent à s'organiser, à développer leurs propres pratiques culturelles, à créer leurs propres champs de résistance et de contre-hégémonie; s'ils leur donnent la possibilité de prendre une position politique. Pour ce faire, une enquête en ligne est menée avec la participation de 493 personnes et les données obtenues ont été évaluées selon ces quatre titres susmentionnés. À la suite des analyses statistiques, il a été conclu que les jeux en ligne massivement multijoueur encouragent les joueurs à développer leurs propres pratiques culturelles (identification avec le groupe) ; à coexister au sein des groupes de jeu sur la base des règles (identification avec le jeu) ; à s'organiser entre eux (interaction sociale) ; à montrer leurs attitudes et comportements critiques, intellectuels et stratégiques; à montrer leurs prises de position sociale, culturelle et politique (interaction entre le jeu et le monde réel) ; à s'impliquer dans des mouvements visant à créer une nouvelle résistance et une contre-hégémonie (activisme hors ligne) à travers des communautés virtuelles établies dans les jeux, en tant que des sujets actifs. Cependant, les joueurs qui jouent aux jeux en ligne massivement multijoueur ne s'engagent dans aucune activité à moins qu'il y ait une intervention dans "l'espace " qu'ils considèrent comme leur espace public. Le fait qu'ils restent passifs, à moins que leurs espaces ne soient perturbés, peut être considéré comme un facteur d'affaiblissement dans le contexte des mouvements de résistance et de contre-hégémonie.

mots-clés: Jeux numériques, hégémonie, contre-hégémonie, jeux en ligne massivement multijoueur, activisme en ligne 


\section{Öz}

Devasa çok oyunculu çevrimiçi oyunların (Massively Multiplayer Online Game - MMOG) yeni bir direniş ve karşı-hegemonya alanı oluşturmayı sağlamada etkili olup olmadığını ortaya koymayı amaçlayan bu çalışma, oyunların oyuncuları pasif ve apolitik bireyler haline getirip getirmediğini sorgulamaktadır. Çalışma kapsamında, çevrimiçi oyunların oyuncuları organize olmaya, kendi kültürel pratiklerini geliştirmeye, kendi direniş ve karşı-hegemonya alanlarını yaratmaya teşvik edip etmediği; ayrıca onlara belli bir politik duruş sergileme fırsatı verip vermediği MMOG oynayanlar aracılığıyla analiz edilmiştir. Araştırma kapsamında 493 oyuncuya çevrimiçi anket uygulanmış, yanıtlarından elde edilen veriler bu dört çerçevede değerlendirilmiştir. Yapılan istatistiksel analizler neticesinde, MMOG oyunların oyuncuları kendi kültürel pratiklerini geliştirmeye (grupla özdeşleşme), oyun grupları içinde kurallar temelinde bir arada var olmaya (oyunla özdeşleşme), kendi aralarında örgütlenmeye (sosyal etkileşim), eleştirel, düşünsel, stratejik tutum ve davranış gösterebilme yetilerini ortaya koymaya, kendi sosyal, kültürel ve siyasal duruşlarını göstermeye teşvik etmeye loyun ve gerçek dünya arasındaki etkileşim); oyunlarda kurulan sanal topluluklar aracılığılla aktif özneler olarak yeni bir direniş ve karşı hegemonya yaratmaya yönelik hareketlere dahil olmalarını (çevrimdışı aktivizm) sağlamaya teşvik ettiği sonucuna ulaşılmıştır. Bununla birlikte çok oyunculu çevrimiçi oyun oynayan oyuncular, kendi kamusal alanları olarak gördükleri "alana" bir müdahale söz konusu olmadığı sürece herhangi bir faaliyette bulunmazlar. Kendi alanlarına müdahale edilmediği sürece pasif bir durumda olmaları bu noktada, direniş ve karşı hegemonya hareketleri bağlamında zayıflatıcı bir unsur olarak değerlendirilebilir.

anahtar kelimeler: Dijital oyunlar, hegemonya, karşı hegemonya, devasa çok oyunculu çevrimiçi oyunlar, çevrimiçi aktivizm 


\section{Giriş}

1970'lerin başlarından itibaren giderek daha çok rağbet gören dijital oyunlar, günümüzde teknolojinin sağladığı simültane deneyimler, etkileşimlilik ve simülasyonla birlikte iletişim bilimleri açısından üzerinde önemle durulması, dikkatle analiz edilmesi ve kültürel öneminin inkâr edilemeyeceği bir konu olarak karşımıza çıkmaktadır. Dijital oyunlarla ilgili yapılan çalışmalar oyun sektörü ve ekonomisi, oyunların olumsuz önyargı ve tutumlara etkisi, çocuk ve gençlerin kültürünün bir parçası olarak oyunlar, dijital oyunların eğitime katkısı gibi konularda öne çıkmaktadır. Özellikle yaygın olan inanış bu tür oyunların, oyuncuları pasif bireyler haline getirdiği yönünde olduğu için, bu perspektiften yola çıkan pek çok çalışma bulunmaktadır. Bununla birlikte geçtiğimiz yıllarda gerçekleşen çeşitli toplumsal olaylar nedeniyle dijital oyunlar, gençler için kamusal bilinç üzerinde politika gündemi ve kamuoyunda geleneksel medyadan daha önemli bir hale gelmiştir (Bevc, 2007, s. 25).

Bu çalışma eleştirel medya okuryazarlığı anlayışından hareketle, dijital oyun oynayanların yaygın kanının aksine yeni iletişim teknolojilerinin "kurbanları" değil, gerçek yaşam ile sanal oyun dünyasını bir arada ve etkileşimli olarak sürdüren aktif bireyler olduklarını savunmaktadır. Özellikle MMOG'ler² tüm yaş gruplarından kadın ve erkek oyuncular tarafından oynanmakta, koordine olmuş gruplar tarafından yalnızca ekranda gözüken birtakım görüntülerle basitçe oyun oynanmasından çok daha öteye gitmektedir. Bu tür oyunlar esasında bireylerin etkileşim halinde oldukları ve bu etkileşimi hissettikleri sanal dünyalardır. Dolayısıyla öncelikle dijital oyunların, bu çalışma özelinde de MMOG'lerin oynanış yapısı ve kurallarının, yukarıda bahsedilen etkileşimi nasıl tetiklediğine bakılmış; kuramsal çerçeve "hegemonya ve karşı hegemonya" kavramları üzerine temellendirilmiştir. Nitekim hegemonik zincirin kırıma noktaları, salt ekonomik indirgemecilikle üretim ilişkileri ve güçleri arasındaki karşıtlık açısından değil, çelişkilerin en çok biriktiği eğilim ve kültürel karşı çıkışların toplandığı gruplar açısından ele alınmalıdır (Laclau ve Mouffe, 2008, s. 106).

Toplum genelinde yaygın olan, yeni jenerasyonun "apolitik" olduğu ve tüm zamanlarını, onları toplumsal olaylar karşısında bilinçsiz ve farkındalığı olmayan bireyler haline getiren dijital oyunları oynayarak geçirdikleri inanışıdır. Özellikle dijital oyunların, oyuncular üzerindeki psikolojik etkileri üzerine yapılan çeşitli araştırma ve çalışmalar bu inanışı pekiştirmektedir. Fakat son yıllarda yaşanan bazı toplumsal hareketlerde, dijital oyun oynayanlar çeşitli protestolarda yer almış; sokak duvarlarına oynadıkları oyunlardan esinlendikleri sloganları yazmış; seslerini oyun esnasında kullandıkları jargon aracılığıyla duyurmaya çalışmışlardır. Dolayısıyla bu çalışma çevrimiçi dijital oyunların, oyuncuların hayatına nasıl entegre olduğunu anlamaya çalışmaktadır, çünkü oyunlar aracılığıyla yaratılan alt kültürler, oyun topIulukları ya da sanal cemaatlerin toplumsal olaylarda nası bir dinamik içerisinde olduğu ve mevcut hegemonyaya karşı oyuncuları siyasi anlamda etkinleştirmeye

2 Devasa Çok Oyunculu Çevrimiçi Oyunlar 
katkısı (Fromme, 2003), yeni medya teknolojileri bağlamındaki yeni toplumsal hareketlerin anlaşılması bakımından önemlidir.

\section{Hegemonya ve Karşı Hegemonya}

Gramsci, hegemonyayı, ulusal nitelikteki isteklerin düğümlendiği bir kavram olarak, bir toplumsal sınıfın diğer bir sosyal sınıf üzerindeki hâkimiyetini, kendi dünya görüşünü ve ideolojisini, zor kullanarak ya da ikna yoluyla empoze etme yeteneği olarak tanımlamaktadır (Gramsci, 2011). Hegemonya, devletin ve ekonominin farklı katmanlarında karmaşık, çelişkili ve beklenmedik bir şekilde ortaya çıkan sivil toplum gibi kuvvet birliklerini ve kilise, ticari birlikler, okul ve aile vb. sosyal kurumları içermektedir; çünkü hegemonya tahakküm altındaki grupların fikir ve kültür alanında da yönetilmesi demektir. Nitekim Klimecki ve Willmott (2011, s. 131)'a göre hegemonya için yapılan mücadele denilince, Marksizm'deki "sınıfların savaşı" anlayışı yerini "kültürel savaş"a bırakmaktadır.

Hegemonyanın egemen ideolojisine karşı olan grupların ideolojileri onları örgütlemekte ve onların harekete geçecekleri, mevcut durumlarının bilincine erip mücadele edecekleri zemini hazırlamaktadır (Gramsci, 2007, s. 82). Toplumdaki marjinalleştirilmiş grupların, hegemonik kurumlara karşı verdiği toplumsal mücadeleler ve karşı hareketler, daha özgür, demokratik ve eşitlikçi bir toplum yapısına doğru ilerleyişin potansiyelini yaratacak şekilde, toplumsal karşıtlıkların geniş alanlara yayılmasını ifade etmektedir. Burada dikkat edilmesi gereken nokta Gramsci'nin hegemonya anlayışının, iktidar dışında kalan sınıflara belli bir direniş alanı vermesidir (Barrett, 2004, s. 80), çünkü ona göre ideoloji, insanların kendi koşullarının farkında olduğu, bu koşulları sorguladığı ve mücadele ettiği, bir diğer ifade ile karşı-hegemonya oluşturmaya çalıştığı bir alanı temsil etmektedir. Esasen aynı toplum içerisinde yönetilenlerle yönetenler arasında bölünmeler olması kaçınılmaz olduğuna göre, yönetici sınıf hiçbir karşıt görüşün öne çıkmasına imkân vermeyecek ilkelerin belirlenmesi için çabalamaktadır. Fakat Gramsci (2007, s. 233)'ye göre bu bir “yanılma"dır, çünkü yönetici sınıf tarafından bir kere bir grubun bağlılı̆ı sağlandı mı, itaatin otomatik olacağı ve sürdürüleceği varsayılmaktadır. Oysa tam bir ideolojik hegemonya nadiren gerçekleşebilir ve gerçekleştiğinde de asla "tam" olamaz; çünkü hegemonya stabil ve değiştirilemez değildir. Storey (2009, s. 81) de hegemonyanın yukarıdan aşağıya doğru bir güç uygulanması durumu değil, egemen sınıf ve toplumdaki diğer alt gruplar arasındaki müzakerenin bir sonucu olduğunu ve bünyesinde mutlaka direnişi barındırdığını vurgulayarak bu görüşü desteklemektedir. Hegemonya iktidara sahip olanlar ve diğerleri arasında bir mücadele alanıdır ve toplum içindeki bazı gruplar hegemonyaya karşı durmaya çalışmakta ve toplum içerisinde bazı karşı-hegemonya yapılanmaları oluşmaktadır (Castells, 2012, s. 14). Laclau ve Mouffe $(2008$, s. 103)'a göre bu bir "hegemonik yeniden düzenleme zeminidir" ve politik pratiklerin demokratik anlamda derinleşmesi ve gelişmesi için bir potansiyel taşımaktadır. Bu noktada ayrı toplumsal grupların, aynı türden olma, kendi bilincine erme ve örgütlenme potansiyellerini fark etme durumu söz konusu olur. Bir grup, başka bir grupla dayanışma halinde olması gerektiğini hisseder. 


\section{Karşı Hegemonya ve Dijital Aktivizm}

Internet ve yeni iletişim teknolojileri, bireylerin politik ve sivil aktivitelere dahil olabilmeleri için yeni yollar açmıştır (Chadha vd., 2012, s. 391). "Politik Çevrimiçi Kullanıcılar" olarak adlandırılan bu bireyler (Smith, 2011, s. 2), toplumsal olaylar, siyaset vs. ile ilgili haberleri ve gündemi takip etmek ve diğer bireylerle tartışmak için çevrimiçi olurlar. Bu nedenle Papacharissi (2009, s. 29)'a göre "yeni iletişim teknolojileri sivil eylemin yeniden keşfedilebileceği araçlar konumundadır".

Castells (2012)'in kitlesel öz-iletişim olarak kavramsallaştırdığı çevrimiçi iletişim hem bireyselliği hem de kolektifliği içermektedir. Bilgisayar başında zaman geçiren bireylerle ilgili yaygın kanının aksine "bu vatandaşlar tek başlarına olmalarına rağmen asla yalnız ya da izole edilmiş değildirler". Yeni iletişim teknolojileri beraberinde yeni toplumsallaşma tarzlarını da getirmektedir. Bakardjieva (2003, s. 291)'nın "hareketsiz toplumsallaşma" kavramsallaştırması da dijital aktivizmin kolektif bir eylem olduğu gerçeğini vurgulamaktadır. Fleissner ve Romano (2007, s. 81)'ya göre dijital aktivizm kolektif bir eylem olmasının yanında ayrıca, toplulukların tepkilerini ve eleştiri kuvvetlerini de güçlendirmektedir.

Dijital aktivizmin teknik alt yapısı dijital ağa ve bilgiyi iletmeye yarayan dijital kodları kullanan bir grup birbiriyle bağlantılı araca dayanmaktadır. Joyce (2010, s. 2)'a göre bu sayede çok sayıda sivil vatandaş birbiriyle kolayca bağlantı kurabildiğinde, birbirlerine çeşitli içerikleri gönderebildiklerinde ya da alabildiklerinde ve farklı hareketlenme ve örgütlenmeleri koordine edebildiklerinde, etkili politik hareketler yaratma fırsatına sahip olmaktadırlar. Bu durum da beraberinde dijital demokrasi, dijital müdahale ve karşı hegemonya hareketleri için bir alan oluşturma potansiyelini getirmektedir (Downey ve Fenton, 2003, s. 199). Bu yeni kamusal alan eğlence, sohbet, film vs. izleme, müzik dinleme vb. gibi boş zaman etkinliklerinin yanında, muhalif ya da alternatif görüşlerin, tartışmaların da yapılabildiği ve karşıt kültürlere yer açabilen bir karşıt kamusal alan olma özelliği de taşımaktadır. Dolayısıyla kamusal alan artık salt iktidar sahiplerinin elinde değil, sivil toplumun da kendisine ait, söz sahibi olabileceği bir alandır (Habermas, 1991, s. 24). Kamusal otoritenin siyasal ve finansal sermayesine karşı, sembolik sermaye ile kendini gösteren bu karşıt gruplar hak iddia ettikleri kamusal alanı, iktidar yapılarına karşı savunmakta, böylece bu grupların meşru taleplerini sergiledikleri bir karşı direniş alanı oluşmaktadır (Bourdieu, 1998, s. 47). Karşıt kamusal alan ve siyasal katılım arasındaki bu pozitif ilişki demokrasiyi güçlendirmektedir (Chadha vd, 2012, s. 392). Artık her çeşit aktivistin ağ aracılığıyla coğrafi, ulusal, ırksal ve hatta ideolojik farklılıklara rağmen örgütlenme özgürlüğü ve olanağı bulunmaktadır (Rushkoff, 2003, s. 53). Bu sayede yeni iletişim araçları, "doğrudan harekete geçme" ya da sınırları çevrimiçi ortamın dışına taşan topluluklar oluşturmak için insanları mobilize etme gibi karşıt kamuların daha geleneksel eylemlerine de aracılık etmektedir (Mouffe, 2000, s. 750-755). 


\section{Devasa Çok Oyunculu Çevrimiçi Oyun Gruplarının Alt Kültürü}

MMOG'ler Steinkuhler (2004) tarafından “bireylerin kendi yarattıkları dijital karakterler ya da "avatarlar" aracılığıyla, yalnızca oyunun yazılımıyla değil, diğer oyuncuların avatarlarıyla da etkileşim halinde olmalarına da olanak sağlayan", yüksek grafikli iki ya da üç boyutlu çevrimiçi dijital oyunlar olarak tanımlamaktadır. Bu tür oyunların diğer dijital oyunlardan en büyük farkı, yalnızca oyun ve oyuncu arasındaki ilişki ile sınırlı kalmaması, diğer oyuncularla da ilişki kurulmasına ve aktif katııma olanak sağlamasıdır. Birden fazla oyuncunun aynı anda oyun arayüzünde bulunması sosyal etkileşimi ve iletişim kurmaya yönelik hareketleri arttırmaktadır.

Yee (2006, s. 309)'ye göre MMOG'lerin bu kadar rağbet görmesi ve dünya genelinde milyonlarca kişi tarafından oynanmasının temel sebeplerinden biri oyuncuları farklı türde motivasyonlarla cezbetmesidir. Bu motivasyon kaynaklarından biri olan rekabet de başarıyı motivasyon kaynağı olarak gören oyuncular için diğerlerine meydan okuma, provokasyon ve hegemonya kapsamında değerlendirilmektedir -ki bu çalışmanın odak noktası hegemonya olması nedeniyle başarı için motivasyon kaynağı olarak ayrı bir önem taşımaktadır. Buradaki hegemonya rekabet ortamı nedeniyle bir diğer takım vs. üzerinde kurulacak bir hegemonyaya işaret etmekle birlikte, gerçek dünya ve oyun dünyası arasındaki etkileşimin daha açık bir şekilde ortaya konulması bakımından altı çizilmesi gereken bir bileşendir.

Oyunu oynama esnasında ya da grupla etkileşim aracılığıyla edinilen kültür, zaman içerisinde grup üyelerinin oyunla ve oyun grubuyla özdeşleşmelerine bu sayede kimliklenme sürecine girmelerine neden olmaktadır. Hemminger (2009, s. 142)'ye göre MMOG oynamak oyunculara, toplumdaki hayal kırıklıkları ve rasyonellikle başa çıkmada alternatif bir yol olmaktadır. Bunun yanı sıra oyuncular için bir anlamlar dünyası üretmek ve ahlaki sistemi yapılandırması gibi işlevleri de vardır. Ayrıca günümüz dünyasında risk toplumlarında kimlik sorunuyla baş etme imkânı da vermektedir, zira bu tür oyunlar oyuncuların kendi kültürleri dâhilinde asla olamayacakları rolleri bürünmelerine izin vermektedir. Bu anlamlı etkileşim, genel olarak toplumda asosyal olarak görülen ve bazı durumlarda toplumdan dışlanan oyun oynayan insanlardan, kamusal alanla ilişkili ve toplumun geri kalanıyla bütünleşmiş yeni bir alanın oluşmasını sağlamaktadır. Gerçek hayat ortamları ile sanal ortamların bütünleşmesi, çevrimiçi ortamların kültürel öneminin büyümesiyle sonuçlanmaktadır, çünkü çevrimiçi ortamlarda kurulan iletişim giderek daha fazla gündelik hayatın arasına sızmaktadır. Böylece sanal ortam kamusal alana dönüşmektedir. Oyuncular bir kamusal alan olarak oyun ortamının kendi kültürünü biçimlendirirken, gerçek dünyaya ait çeşitli kuralları modifiye ederken, kendine ait yeni bir dil yaratırken, kültürel ve toplumsal sınırlar boyunca birtakım artefaktlar yarattığını öne sürmektedirler. Dolayısıyla bir kimlik yapılanması ortamı olarak oyun kültürü, sanal ve gerçek dünya arasındaki ayrıma odaklanma sorusunu da beraberinde getirmektedir. 
Tıpkı sosyal medya platformları gibi çevrimiçi oyunlar da 7/24 aktif olan bir enformasyon ağı durumundadır. Geleneksel medya temsili iken, yeni medyanın içerisinde tanımlanan çevrimiçi oyunlar simülasyona dayalıdır. Simülasyona dayalı bir kitle medyasının bilişsel sonuçlarından en önemlisi merkezileşmemiş düşünce yapısını desteklemesidir (Frasca, 2003). Bu nedenle çevrimiçi oyunlar tıpkı internet temelli ağ toplumları gibi kendi mantığı ve bileşenleri yardımıyla kendi kendine örgütlenen (self-organization) bir sistemdir. Kendi mantığı ve amaçları vardır; basit öğelere indirgenemez, çünkü sistemin öğeleri arasındaki etkileşimlerden ortaya çıkar. Bundan dolayı kendini oluşturan öğelerden daha fazlasıdır (Fuchs, 2008, s. 11).

Kendi kendine örgütlenen sistemler olarak çevrimiçi oyun toplulukları, kendi içsel koşullarından ve içinde bulundukları çevrenin koşullarından etkilenmektedir. Bunun dışında çevrimiçi oyun toplulukları bünyesinde sinerji, yenilik, kendisini oluşturan parçalara indirgenemezlik, öngörülemezlik, uyum ve korelasyonu barındırmaktadır (Fuchs, 2008, s. 14-15). MMOG oyun yapısı oyuncuları çoğunlukla oyundaki görevleri tamamlamak için iş birliği yapmaya ve sosyalleşmeye zorlar. Buna ek olarak internet, çevrimiçi oyun topluluklarına düşüncelerini, değerlerini ve bilgileri paylaşabilmeleri için muazzam bir altyapı sunmakta ve dolayısıyla uluslararası çevrimiçi oyuncu hareketliliklerine olanak tanımaktadır (Hemminger, 2009, s. 19).

Toplum genelinde yaygın olan inanış bilgisayar başında çok zaman geçiren bireylerin asosyal ve apolitik olduğu yönündedir. Oysa MMOG topluluklarında üretilen sosyal sermaye göz ardı edilemez bir gerçekliktir ve Hemminger (2009, s. 53)'e göre oyunların "sihirli dünyasına" kendini kaptıran oyuncuların gerçeklikten kaçtıkları ve oyunların gündelik hayatta hiçbir işe yaramadığı varsayımları yeniden gözden geçirilmelidir. Burada sorulması gereken soru, "çevrimiçi ortamlarda çok fazla zaman geçiren bireylerin, gündelik yaşamlarında bu kadar apolitik, pasif ve asosyal görülürken, herhangi bir toplumsal harekette nasıl bu kadar aktif; politik, toplumsal ve ekonomik olaylar konusunda bilgilenmiş oldukları ve bu konularda çevrimiçi ortamlarda nasıl olup da bu kadar hızlı bir şekilde ortak duyu geliştirdikleridir" (Hemminger, 2009, s. 53). Schudson (1998)'un ortaya koyduğu "Monitöryal Vatandaş3" tam da bu noktayı anlamakta oldukça yardımcı bir kavramsallaştırmadır. Schudson (1998, s. 311)'a göre monitöryal vatandaşlar okumaktan ziyade tararlar (scan); bilginin dolanımda olduğu çevreyi gözlemlerler. Bu sayede çeşitli sorunlara karşı tetikte olmakta ve çok farklı yollarla o sorunlar etrafında "seferber olmaktadırlar". Monitöryal vatandaşlar proaktif olmaktan ziyade "savunmacı"dırlar. Politik, ekonomik ve sosyal olayları "taramakta", gözden geçirmektedirler. Dışarıdan bakıldığında "pasif" görülen bu bireyler gerektiği takdirde eylem için harekete geçmektedirler. Monitöryal davranışı harekete geçiren, medya tarafından sunulan "bilgi bombardımanını" yönetme ve vatandaşlık görevlerini az da olsa yerine getirme ihtiyacıdır. Geleneksel medya, siyasal çevreyi tarayan ve gerektiğinde mobilize olabilen çağdaş monitöryal vatandaşa bilgiye ve iletişime erişimde 3 Michael Schudson (1998)'un "The Good Citizen" adlı kitabında ortaya koyduğu "Monitorial Citizen" (Monitöryal Vatandaş) okumaktan ziyade ekranı tarayan (scan); bilginin dolanımda olduğu çevreyi gözlemleyen ve gerektiğinde belli bir sorun etrafında seferber olan üç vatandaş türünden biridir. Bu kavramdaki monitör bilgisayar ve/veya televizyon ekranına gönderme yapmaktadır. 
sınırlı ve yapılandııımış fırsatlar ve hareket tarzı sunarken, internet aracılığıyla kurulan iletişim bireylere forumlar aracılığıyla düşüncelerini açıkça ifade etme olanağı sunmaktadır (Papacharissi, 2009, s. 37-38). Monitöryal davranış oyuncuların gündelik hayatta pasif, apolitik bireyler gibi bir duruş sergilerken, herhangi bir toplumsal olay karşısında örgütlenip, faaliyete geçtiklerini açıklayan bir yaklaşımdır.

\section{Araştırmanın Yöntemi}

Çevrimiçi oyunların, oyuncuları pasifleştirmekten ziyade, onları kendi kültürel pratiklerini geliştirmeye, kendi aralarında örgütlenme ve direniş alanlarını oluşturmaya ve sosyal, siyasal, ekonomik, güncel olaylarda kendi duruşlarını göstermeye teşvik edip etmediğinin ve oyunlarda kurulan sanal topluluklar aracılığıyla muhalif hareketlere dâhil olup, karşı hegemonya yaratmaya yönelik hareketlerde aktif özneler olup olmadıklarının ortaya konulması bu çalışmanın temel amacıdır. Bu çalışmanın temel varsayımı "devasa çok oyunculu çevrimiçi oyunlar, çevrimiçi oyuncu topluluklarına yeni bir direniş ve karşı-hegemonya alanı sağlamaktadır" şeklindedir ve çalışma bu varsayımdan yola çıkarak yürütülmüş; çevrimiçi oyun oynamanın gerçek dünyadaki direniş hareketlerine etkisini ortaya koyma amaçlı olarak dört adet boyut belirlenmiş; araştırma sorusu ve hipotezler bu boyutlar bağlamında oluşturulmuştur:

Birinci Boyut - Kimliklenme Süreci: Huizinga (1980, s. 11) oyunların etkilerinin yalnızca oyunun oynandığı fiziksel ortamda kalmadığını, aynı zamanda oyuna katılanların çeşitli fikirleri ve değerleri deneyimleyebildiği bilişsel bir yapılanma süreci olduğunu vurgulamaktadır. MMOG oynamanın sivil karakteristikleri, oyuncuların oyun oynarken de sivil deneyimlere sahip olmalarını sağlamaktadır. Bir oyuna katılmak, diğer oyuncuların kendi hareketlerine ne tepki vereceğini öngörmeyi gerektirmektedir. Nihayetinde oyuncular, oyun grubu içerisinde genel ve yaygın perspektifleri içselleştirmelerini sağlayan bir şekilde diğer oyuncuların bakış açılarını anlama yeteneğine sahip olmaktadırlar. Yani bir grup ya da toplulukla özdeşleşmektedirler. Van Looy vd. (2010, s. 128) göre MMOG'ler, oyuncuların kendi kimliklerini sosyal bir bağlamda tecrübe etmelerine izin vermesi, çevrimiçi oyunların özdeşleşme boyutuyla yakından ilgilidir. Böylece çok oyunculu çevrimiçi oyun, oyunculara grup özdeşleşmesi ve oyun (topluluk) özdeşleşmesinin yolunu açmaktadır. Ortak arkadaş etkileşimleri chat (sohbet) yapmanın yanında "buffing" yani takım arkadaşını pohpohlama ve "gaza" getirme, "kill assisting" yani gruptan başka bir oyuncuya, karşılık beklemeksizin rakibi yok etmesinde yardımcı olmak ve daha zayıf bir karaktere tehlikeli bir bölgede eşlik etmek bunlar arasında sayılabilir. Oyun üyeleri arasındaki bir chat (sohbet) kanalı bu tür hareketlilikleri organize etme ve karşı takıma karşı mücadele etmede ve görevin sonunda ganimetin paylaşılması konusunda düzenleme yapmakta kullanılmaktadır. Çok daha fazla sayıda oyuncu içeren daha büyük mücadelelerde ise oyuncuların bağlantıda oldukları "raid chat (sohbet) kanalları" oluşturulmaktadır. Tüm bu sayılan oyun etkileşimleri oyunun yalnızca oyuncuların avatarları arasında gerçekleşip bitmesinin önüne geçmekte, oyunun yapısı oyuncuların "oyunla özdeşleşme" sürecini etkileyip, oyunun dışına taşmasına izin vermektedir. Buna göre; 
Hipotez 1: MMOG'lerin oyun yapısı ve oyun esnasındaki buffing, kill assisting, eşlik etme gibi etkileşimler "oyunla özdeşleşme"yi pozitif yönde etkilemektedir.

İkinci Boyut - Sosyal Etkileşim: MMOG'lerin oyun yapısı, oyundaki pek çok görevi tamamlamak için oyuncuları iş birliği yapmaya (bu sayede de sosyalleşmeye) zorlamaktadır. Dolayısıyla MMOG'ler, oyuncuların kişisel profillerini oluşturup, diğer oyuncularla da etkileşime girdikleri bir sosyalleşme platformudur. MMOG, oyuncuları arkadaşlık sistemi, tartışma forumu, ortak ilgi grupları vb. gibi ağ aracılığı ile kurulan iletişimle birbirlerine bağlamaktadır. Farklı alt sistemlerden oluşması, toplulukların tartışma forumları ya da ortak ilgi grupları formunda örgütlenmelerine olanak sağlamaktadır. Bununla birlikte devasa çok oyunculu çevrimiçi oyunlar, birbirinden fiziksel olarak uzak olan oyuncuların siberalanda konumlandırarak oluşturduğu ve akabinde sanal topluluklar haline dönüştüğü, bu nedenle kendi uzamını yaratan bir sistemdir. Oyun sisteminin sağladığı bu fonksiyon beraberinde, mail sistemleri, bülten gönderim sistemleri ve hatta çevrimiçi olan insanların listesi aracılığıyla gerçek dünyada da topluluğa dahil olmayı getirmektedir. Buna göre;

Hipotez 2: MMOG oynamak ile oyuncular arasındaki sosyal etkileşim arasında pozitif bir ilişki vardır.

Üçüncü Boyut - Oyun Topluluğu ve Gerçek Dünyadaki Topluluk Arasındaki illişki: Oyuncuların sosyal ve topluluğa dair etkileşimleri, takımlar içerisinde bulunabilen sosyal ağlar gibi yapısal birtakım özellikleri inşa etmektedir ve oyuncuların uzun dönemli arkadaşlıklar ve takım-grup içi ilişkileri muhafaza etmelerini sağlamaktadır (Küklich, 2007, s. 14). Oyunların etrafında ortaya çıkan çevrimiçi oyun toplulukları teşvik edici bir topluluk olarak işlev görmekte, üyeleri kimlikler, değerler ve pratiklere bağlamaktadır. Tüm bunlar sonucunda MMOG oynamak, potansiyel olarak farklı ve daha anlamlı sosyal etkileşimlere yol açmakta ve böylece bir "oyun topluluğu" oluşumu için fırsat yaratmaktadır. Buna göre;

Hipotez 3a: Takım ve genel sohbet vs. aracılığıyla kurulan sosyal etkileşim ile oyun topluluğu oluşumu arasında pozitif bir ilişki vardır.

Hipotez 3b: Oyun topluluğuyla güçlü bir şekilde özdeşleşen oyuncuların diğer oyuncularla uzun dönemli anlamlı ilişkiler kurmak, sohbet etmek ve onlara yardım etmek için daha güçlü arzuları ve ilgileri vardır.

MMOG aracılığıyla kurulan iletişim bireylere, toplulukları, blogları, forumları vb. aracılığıyla yürüttükleri etkileşimleri, karşılıklı bilgi alışverişi, siyasal ve ekonomik tartışmaları hakkında gerçek dünyada da mobilize olma fırsatı yaratmaktadır. Sanal oyun toplulukları uzamsal olarak sabit olmayan ve teknoloji aracılı devamlı iletişimin sosyal ortamları, alanlarıdır. Bu ortam ve alanda gerçekleşen buluşmalarda, anlamlar ve yorumlar, belli bir ölçüde ortak anlam ya da yorumlar ortaya çıkana kadar tartışımaktadır. Oyunlar oynanırken başlayan kimlik inşa süreci - ki 
bu kimlikler çevrimdışı hayat üzerine temellenmekte ve onunla bağlantılı olmaktadır- sürekli değişen çevrimiçi eylemlerle devam etmekte ve geri bildirimleri çevrimdışı dünyaya olmaktadır.

Oyunun senaryosu ve karakterleri/avatarları oyuncuların oyun topluluğunun bir üyesi olması ve gerçek dünyada da birlikte mücadele etmeleri yönünde onları cesaretlendirmektedir. Bundan dolayı birlikte herhangi bir şeye karşı bir araya gelme yeteneğine sahip olmaktadırlar. Özdeşleşme sürecinin oyuncular üzerinde çok büyük bir etkisi olmaktadır, çünkü oyuncular, oyunda kolektif olarak nasıl davranıyorlarsa, gerçek dünyada da aynı şekilde davranmaya, hareket etmeye çalışmaktadırlar. MMOG oynamak oyunla özdeşleşme süreci yaratmakta ve oyuncular aynı duyguyu gerçek dünyada da hissetme intiyacı duymakta, aynı ambiyansı, tatmini ve topluluk olma hissini aramaktadırlar. MMOG yapısı, oyunla özdeşleşme, takım çalışması ve görevleri tamamlamanın oyuncuların gerçek dünyadaki davranışları, sosyal etkileşimleri ve ilişkilerinde büyük bir etkisi olmaktadır. Oyun, bir anlamlandırma süreci olarak sıradan hayatın ötesine geçmekte ve oyuncuların bazı konuları/sorunları izole edilmiş olmaktan çıkarmalarını sağlamaktadır. Bu türlü kişisel enformasyon ortamlarının gelişimi yalnızca çevrimiçi ortamla sınılı kalmamakta, sanal ortamlarda bir araya gelen bireyler düzenli olarak "gerçek dünya buluşmaları" da düzenlemekte, avatarların arkasındaki oyuncular bireysel olarak da tanışmaktadırlar (Deuze, 2007). Buna göre;

Hipotez 3c: MMOG oyun topluluğu üyesi olan oyuncular büyük olasılıkla oyun dışında gerçek dünyada da buluşmaktadır.

Dördüncü Boyut - Çevrimdışı Aktivizm: Oyundaki simultane deneyimler gerçek hayattaki becerilerin kazanılmasında etkilidir. Oyun esnasında çeşitli politikalarla hayatta kalma, savaşma vs. yapan oyuncunun gerçek hayattaki politika ile ilgili öz-yeterliği de gelişmiş olmaktadır (Bevc, 2007, s. 33).

Çevrimiçi kanallar konvansiyonel formlardaki politik duruşun tamamlayıcısıdır ve bundan başka bireylerin sivil aktivizmini teşvik eden faktörler durumundadır; çünkü bireylere "halkın ruhunu yansıtan" ifadeleri kullanabilecekleri bir ortam sağlamaktadır (Shah vd., 2007, s. 677). Bu nedenle oyuncuların oyun toplulukları aracılığıyla toplumsal gerçekliğe yönelik farkındalıkları artmaktadır. MMOG oyuncuların, çevrimiçi ortamda elde ettikleri görüşleri, değerleri, bakış açılarını gerçek dünya yapılarına yansıtmalarını ve toplum içinde güç ve iktidar yapılarının nasıl paylaşılması gerektiğini dikkate almalarını sağlamaktadır. Böylece oyuncular gerçek dünyada olan olaylar hakkında çevrimiçi oyun topluluğu aracılığıyla bilgilenmekte ve organize olmaktadırlar. Oyun esnasında tek bir insanın bile bir şeyleri değiştirebileceğinin farkına varan oyuncu, kendi bireysel eylemlerinin gerçek dünyada da bir fark yaratacağına inanmaktadır. Ayrıca oyun oynarken simülesivil ${ }^{4}$ eylemlerin, diğer oyunculara yardım ya da kılavuzluk etmenin, takım yönetme ya da organize etmenin (sosyal ağ geliştirmek için bir fırsat), toplumsal sorunları öğrenmenin ve

4 Sivil eylemlerin çevrimiçi ortamda simüle edilmesi 
sorunlarla mücadele etmenin, sivil ve politik aktivitelere karşı, sivil oyun deneyimlerine sınırlı olarak maruz kalmaktan daha büyük bir bağılık ve katııım göstermeye etkisi bulunmaktadır. Oyun oynamanın sosyal bağlamı, oyunla özdeşleşme süreci ve oyuncular arasındaki sosyal etkileşimin sivil ve politik katılımla doğrudan ilişkisi bulunmaktadır. Buna göre;

Hipotez 4a: Bir oyun topluluğu üyesi olmak oyunculara gerçek dünyada organize olma ve protestolara katıma, yardım toplama vb. gibi birlikte hareket etme potansiyeli sağlayabilir.

Çevrimiçi iletişim bireysel bir uğraş muamelesi görse bile, kolektif bir sinerjiyi de içermekte ve herhangi bir toplumsal olayda, çevrimdışı iletişim süreçleriyle eşzamanlı ilerlemektedir. Bundan dolayı çevrimiçi aktivitelerin çeşitli toplumsal eylemlerde, kişilerarası iş birliği ve örgütlenmeyi koordine etmede çok önemli rolü bulunmaktadır. MMOG yapısı, oyuncuların güç ve hiyerarşik yapılanmaya yönelik bakış açılarını da etkilemektedir. Bu nedenle herhangi bir siyasaya muhalif olup iletişim kurduklarında, çevrimiçi ortamda olduğu gibi gerçek dünyada da direniş gösterebilir ve protesto hareketlerine katılabilirler. Buradaki esas nokta çok oyunculu çevrimiçi oyunlarda zamanlarının çoğunu harcayan bireylerin, nasıl olup da aktif ve siyasal, ekonomik ve toplumsal olaylar hakkında yeterince bilgilendirilmiş olabilecekleri ve gündem hakkında nası hızlı bir Şekilde ortak duyu yarattıkları sorusudur. Monitöryal davranışa göre sanal bir topluluğa üye olan bireylerin pasif ve apolitik bir duruşu vardır (Schudson (1998, s. 311). Bununla birlikte herhangi bir toplumsal olay ya da harekete karşı organize olabilmektedirler, çünkü onlar okumamakta; bunun yerine taramakta (scan), gözlemlemekte ve tartışmaktadırlar ve gerekirse iktidarın siyasalarına karşı mobilize ve organize olmaktadırlar. Internetin heterarşik ve merkezi olmayan yapısı sanal topluluklar ve dolayısıyla katılım, yeni toplumsal hareketler ve siber protestoların oluşumu için gerekli ön koşulları sağlamaktadır. Buna göre;

Hipotez 4b: MMOG oyun topluluklarının muhalif oldukları durumlarda karşı direniş gösterme ve protesto etme potansiyeli vardır.

Internet temelli çevrimiçi kanallar aracıı̆ğıla oluşan çevrimiçi topluluklar, heterarşik karşıt kültürleriyle siyaset, ekonomi, kültür ve din vb. konulara hâkim olduklarından, toplumdaki egemen yapıların hegemonyasını yok etme olmasa bile, sarsma, ona meydan okuma fırsatı elde eder; "onların hikayeleriyle kendi hikayelerini yer değiştirirler". Benzer şekilde yine çevrimiçi kanallar, karşıt kültürlerin birlik olarak "mevcut gerçekliği" teknoloji aracılığıyla değiştirmeye adamış "grassroot ${ }^{5}$ ", "kendi işini kendin yap", "cyberpunk6" hareketlerini ateşlemektedir. Farklı topluluklarda gelişen bu tür sosyal ağlar aracılığıyla geliştirilen aktivist hareketlerin etkili olabilmesi, hoşnutsuzluklarını ve kendi taleplerini ifade edebilmeleri ve görmezden gelinmemeleri için daha büyük ölçekli hareketlere ihtiyaçları

5 Taban örgütlenmesi

6 Zamanının çoğunu sanal alemde geçiren yüksek teknoloji ve düşük gerçek yaşam tarzını seçen birey 
olmaktadır. Dolayısıyla bu tür hareketler için farkıı topluluklardan çevreci, öğrenci, etnik ve yerli hakları aktivistleri, dini gruplar ve hatta rap, rock, alternatif müzik dinleyenler, çevrimiçi oyun oynayan vb. insanlar bir araya gelmektedir. Amaçları mevcut hegemonyaya meydan okumak, karşı hegemonya hareketleri yaratmaktır. Bu tür gruplardan biri olan çevrimiçi oyun topluluklarının karşı hegemonya hareketleri yaratmadaki etkisi ve MMOG'lerin oyunculara, karşı hegemonya alanı yapılandırmada sunduğu fırsat gözden kaçııımaması ve incelenmesi gereken bir husus olmaktadır. Buna göre;

Araştırma Sorusu: MMOG'ler karşı hegemonya alanı yapılandırmada ve oyun topluluklarının aktivizmi karşı hegemonya hareketlerinde etkili midir?

Araştırma yöntemi kapsamında oluşturulan hipotezleri test etmek amacıyla politik katılım ölçeği ve modelleme (Gil de Zúñiga vd, 2007; Gil de Zúñiga ve Valenzuela, 2010) ve Bekhtina (2002)'nın “Psychological Research of MUD Gamers" adlı çalışmalarının yanında Utz (2000)'un "Social Information Processing in MUDs: The Development of Friendships in Virtual Worlds" adlı çalışması temel alınarak bir anket hazırlanmıştır. Hazırlanan anket çevrimiçi anket hizmet alımı ile örnekleme uygulanmıştır.

Araştırma kapsamında yürütülen çevrimiçi anket toplamda Türkiye'deki Facebook Oyun Gruplarında ve Türkiye'deki e-spor takımlarında aktif olan 479.258 kişi ile paylaşılmıştır. 100.000 ve üstü sayıda evren büyüklüğünde, +- 0.05 örnekleme hatası ve $p=0.5$ ile $q=0.5$ olmak üzere 495 kişi ankete katılmıştır. Anket analizleri öncesinde ankete katılanların cevapları genel bir taramadan geçirilmiştir. Yarım bırakılan anketlerin verilerin analizi açısından sağlıklı sonuçlar almaya olumsuz etkisi olabileceğinden dolayı, tüm bu anketler analiz dışında bırakılmıştır. Analizler SPSS 22 İstatistik Paket programı kullanılarak 435 kişiyle yapılmıştır.

Ankete katılan oyuncuların grupla özdeşleşme, sosyal etkileşim ve çevrimdışı aktivizm arasındaki ilişkiyi hangi değişkenler üzerinden değerlendirdiğini ve bu değişkenlerin kaç faktör altında toplandığını belirlemek amacıyla açımlayıcı faktör analizi yapılmıştır. Faktör analizinde ve hipotezler çerçevesinde belirlenen soruların dört boyut altında toplanması beklenmiştir. Faktör analizinin yapılabilmesi için her ifadeye uygun sayıda yanıt alınıp alınmadığını görmek üzere, ayrıca yanIış kodlama, normalaltı ya da normalüstü ifadelerin belirlenebilmesi için frekans analizi yapılmıştır. Ankette sorulan ilk sorular demografik verilere ilişkindir. 
Tablo 1. Katıımcıların Yaş, Eğitim Seviyesi ve Gelir Dağıımı

\begin{tabular}{|ll|r|r|r|}
\hline & & \multicolumn{1}{|c|}{ Yaş } & Eğitim seviyesi & Aylık ortalama hane geliri \\
\hline N & Geçerli Oran & 423 & 430 & 373 \\
& Kayıp Veri & 7 & 0 & 57 \\
Mean & & 20,9480 & 3,2256 & 4518,6488 \\
Median & 20,0000 & 4,0000 & 3500,0000 \\
Mode & 18,00 & 4,00 & 5000,00 \\
Std. Sapma & 5,27195 & 1,08510 & 4301,59821 \\
Minimum & 13,00 & 1,00 &, 00 \\
Maksimum & 57,00 & 6,00 & 45000,00 \\
\hline
\end{tabular}

Ankete katılan oyuncuların \%94'ü erkek, \%6'sı kadındır. Dijital oyun oynayanların büyük çoğunluğunun erkek olması Cassell ve Jenkins (1998, s. 8)'e göre çocukların büyüme çağında teknoloji ile olan bağlantılarının yoğunluğuna dayanmaktadır. Buna göre kız çocuklar erkek çocuklarına göre toplumsal cinsiyet bağlamında bilgisayar teknolojileri ile daha az ilgilenmektedirler. Bununla birlikte son yıllarda kadın oyuncu sayısında büyük bir artış gözlemlenmektedir. Yine de bu çalışmaya katılan oyuncuların büyük oranda erkek olmasının, kadın oyuncuların çevrimiçi oyunlar yerine daha çok bireysel oyunları tercih etmesinden ve MMOG tarzı oyunların kadın oyunculara hitap etmemesinden kaynaklanmakta olduğu söylenebilir.

Katılımcıların yaşları, eğitim durumları ve aylık ortalama hane gelirlerini gösteren tabloya göre ankete katılanlar arasında en fazla 18 yaş grubu, üniversite düzeyinde eğitim ve 5000 TL ortalama hane geliri görülmektedir. Ortalama yaş yaklaşık 21 iken, ortalama aylık hane geliri yaklaşık 4500 TL civarındadır.

Tablo 2. Katılımcıların Oyun Oynama Sıklıkları

\begin{tabular}{|ll|r|r|r|}
\hline & Frekans & Oran & \multicolumn{1}{l|}{ Geçerli oran } \\
\hline Geçerli Veri & Canım sıkıldıkça & 14 & 3,3 & 3,3 \\
& Günde 6 saate kadar & 145 & 33,7 & 34,1 \\
& Günde 6 saatten fazla & 50 & 11,6 & 11,8 \\
& Haftada 3 güne kadar & 61 & 14,2 & 14,4 \\
& Haftada 3 günden fazla & 30 & 7,0 & 7,1 \\
& Her gün & 125 & 29,1 & 29,4 \\
& Toplam & 425 & 98,8 & 100,0 \\
Kayıp Veri & Sistem & 5 & 1,2 & \\
Toplam & & 430 & 100,0 & \\
\hline
\end{tabular}


Katılımcılar oyun oynama sıklıkları sorusuna en fazla "günde altı saate kadar" $(\% 34,1)$ ve "her gün" $(\% 29,4)$ yanıtını vermişlerdir. Oyunun oynanma sıklığı "her gün" ve "günden altı saatten fazla" olduğu için oyuncular arasındaki iletişim daha fazla olmaktadır. Dolayısıyla oyun grubu içerisindeki sosyal etkileşim ve devamında kurulan gerçek dünya arkadaşlıkları harcanan zamanının çokluğu ile desteklenmektedir.

Katılımcıların çevrimiçi oyun oynama biçimi tercihleri sorulduğunda en fazla tercih edilen oynama biçimi "guild meet-ups"lar olduğu görülmektedir. Guild meet-ups'lar, oyun içerisinde belli bir görevi yerine getirmek için, belli bir süreliğine bir araya gelen takımlardır. Küçük bir alanda yerel internet bağlantısı kapsamında özellikle internet kafelerde turnuva esnasında oynama Şekli olan LAN buluşmalar için tercih edilme oranında belli bir kutuplaşma bulunmamaktadır. Nitekim internet kafe ya da benzer bir Şekilde küçük bir alanda oyun oynamak yerine herkesin kendi evinin rahatlığı ve konforundan çevrimiçi olup bir araya gelmeyi tercih etmeleri bu durumun açıklaması olarak görülebilir.

Oyun esnasında en az düzeyde konvansiyonel buluşmaların tercih edildiği görülmüştür, çünkü bu tür oyun oynama biçimi genellikle özel organizasyonlarda kullanılan oynama biçimleridir. Bunun dışında kalan "guild meet ups", küçük gruplar ya da bir-iki oyuncuyla bir araya gelme tercih edilen oynama biçimleridir, çünkü bu tür oyun oynama biçimlerinin sınırları daha esnektir. Oyuncu bazen canı sıkıldığında çevrimiçi olup, oyun topluluğundan arkadaşlarının orada olup olmadığına bakmakta ve orada olanlarla "bir maç" atmaktadır. Ortak karar alınarak bir araya gelinen "guild meet ups"lar dışında, farklı server tercih edip, hiç tanımadıkları insanlarla oynamayı da tercih edebilmektedirler.

Anket verileri SPSS programında analiz edilmiş ve KMO değeri .94 olarak tespit edilmiştir. Bu değer ile çalışmanın örneklem büyüklüğünün faktör analizi için "mükemmel" olduğu sonucuna ulaşılmıştır. Barlett küresellik testi sonuçları ise ki-kare (X2 = 17616,348; $p<.00)$ değerinin anlamlı olduğunu göstermektedir. Buna göre verilerin çok değişkenli normal dağılımdan geldiği ve faktör analizi için uygun olduğu görülmüştür. Genel olarak tüm soruların Cronbach's Alpha değeri .976 olduğundan verilerin güvenilirliğinin oldukça yüksek olduğu söylenebilir. Açımlayıcı faktör analizinde yapının kaç faktörden oluştuğunun belirlenmesinde yamaç birikinti grafiği, Kaiser-Guttmann ilkesi ve faktörlerin anlamsal bütünlüğüne bakılmıştır. Açıklanan Toplam Varyans tablosu incelendiğinde öz değeri 1 'in üzerinde olan 11 maddenin yer aldığı ve bu 11 maddenin toplam varyansın \%67.2'sini açıkladığı görülmüştür. Yamaç Birikinti Grafiği incelendiğinde ise beşinci faktörden itibaren eğim plato yapmaktadır ve diğer faktörlerin varyansa yaptıkları katkılar hemen hemen aynıdır.

Araştırmanın hipotezleri doğrultusunda faktör sayısı dört olarak belirlendiğinden faktör analizi özdeğer yerine faktör sayısı dört olarak hesaplama tekrar yapılmıştır. Ortak Varyans (Communalities) tablosu yeniden incelendiğinde verilerin 
anlamlıı̆̆ını zayıflatan çıkartma değeri 0.30'un altında olan ve faktör yük değerleri arasındaki fark 0.10'dan küçük olan toplam dokuz madde çıkarılmıştır.

Tüm elemelerin yapılmasının ardından faktör analizinde dört faktör altında toplanan 67 maddelik bir ölçek elde edilmiştir. 67 maddeden oluşan ölçeğin Cronbach Alfa Güvenilirlik katsayısının 0.976 olduğu; dolayısıyla ölçeğin iç tutarlıı̆̆ının yüksek olduğu görülmektedir.

Tablo 3. 67 Maddeden Oluşan Ölçeğin Güvenirlik Sonuçları

\begin{tabular}{|c|c|c|}
\hline Cronbach's Alpha & $\begin{array}{c}\text { Cronbach's Alpha Ba- } \\
\text { sed on Standardized } \\
\text { Items }\end{array}$ & N of Items \\
\hline, 976 &, 976 & 67 \\
\hline
\end{tabular}

Dört faktörün de toplam geliştirilen ölçeğin toplam varyansı açıklama oranı \%57'dir. Tabloda döndürülmüş varyans açıklama oranları arasındaki farkın daha az olduğu; birinci faktörün toplam varyansın \%22'sini, ikinci faktörün toplam varyansın \%16'sını, üçüncü faktörün toplam varyansın \%10'unu, dördüncü faktörün de yine toplam varyansın \%9'unu açıkladığı görülmektedir.

Döndürülmüş Faktör Matrisi (Varimax) analizine sonuçlarında, soruların aldıkları faktör yüklerine göre yer aldıkları boyutlara bakıldığında 28 maddenin üçüncü boyut (Oyun-Gerçek Dünya Etkileşimi: Cronbach's Alpha ,969), 22 maddenin ikinci boyut altında (Oyunda Sosyal Etkileşim: Cronbach's Alpha ,938), 10 maddenin birinci boyut altında (Kimliklenme Süreci: Cronbach's Alpha ,876), yedi maddenin ise dördüncü boyut altında (Çevrimdışı Aktivizm: Cronbach's Alpha ,884) toplandığı görülmektedir. Yukarıda da görüldüğü üzere boyutlara göre faktörleşme, analizler yapılmadan önce boyutlar için belirlenen sorular altında olmuştur. Ardından iki değişken arasındaki doğrusal ilişkinin gücünü belirleyen Pearson Korelasyonu Analizi yapılmıştır. Analizde 0,70'den büyük değerler güçlü, 0,70-0,30 arası değerler orta, 0,30'dan küçük değerler ise korelasyonlar arasında zayıf bir ilişki olduğunu göstermektedir. Araştırma sorusu ve hipotezleri doğrultusunda boyutlar arasındaki ilişkinin yönü ve büyüklügünü ölçmek üzere Pearson Korelasyon Analizi yapılmıştır. 
Tablo 4. Pearson Korelasyonu Tablosu

\begin{tabular}{|ll|r|r|r|r|}
\hline & & $\begin{array}{l}\text { Oyun gerçek } \\
\text { dünya etkileşimi }\end{array}$ & $\begin{array}{l}\text { Sosyal } \\
\text { etkileşim }\end{array}$ & $\begin{array}{l}\text { Kimliklenme } \\
\text { sureci }\end{array}$ & $\begin{array}{l}\text { Çevrimdışı } \\
\text { aktivizm }\end{array}$ \\
\hline $\begin{array}{l}\text { Oyun gerçek } \\
\text { dünya etkileşim }\end{array}$ & Pearson Correlation & 1 &, $788^{* *}$ &, $504^{* *}$ &, $617^{* *}$ \\
& Sig. (2-tailed) & &, 000 &, 000 &, 000 \\
& $\mathrm{~N}$ & 363 & 318 & 342 & 351 \\
\hline Sosyal etkileşim & Pearson Correlation &, $788^{* *}$ & 1 &, $662^{* *}$ &, $470^{* *}$ \\
& Sig. (2-tailed) &, 000 &, 000 &, 000 \\
& $\mathrm{~N}$ & 318 & 362 & 342 & 349 \\
\hline Kimliklenme & Pearson Correlation &, $504^{* *}$ &, $662^{* *}$ & 1 &, $334^{* *}$ \\
sureci & Sig. (2-tailed) &, 000 &, 000 &, 000 \\
& $\mathrm{~N}$ & 342 & 342 & 399 & 378 \\
\hline $\begin{array}{l}\text { Çevrimdışı } \\
\text { aktivizm }\end{array}$ & Pearson Correlation &, $617^{* *}$ &, $470^{* *}$ &, $334^{* *}$ & 1 \\
& Sig. (2-tailed) &, 000 &, 000 &, 000 & \\
& $\mathrm{~N}$ & 351 & 349 & 378 & 403 \\
\hline
\end{tabular}

**. Korelasyon 0.01 düzeyinde anlamlıdır (2-tailed).

Faktörler arası korelasyon analizinin sonuçlarına göre tüm Sig. (2-tailed) değerleri ,000 olarak hesaplanmıştır. Bu durum \%99 güven aralığında $(p<0.01)$ faktörler arasında doğrusal ve pozitif bir ilişki olduğunu göstermektedir. Faktörler arası korelasyon katsayılarının tümü pozitif bir değere sahiptir. Buna göre faktörlerden birindeki artışın diğer faktörlerde de artışa neden olacağı söylenebilir. Bu artışın gücünü belirleyen ise korelasyon katsayılarının büyüklügüdür. Buna göre Pearson Korelasyonu Tablosu incelendiğinde;

. "Sosyal Etkileşim" ve "Oyun ve Gerçek Dünya Arasındaki Etkileşim" boyutları arasındaki ilişkinin pozitif ve oldukça yüksek düzeyde olduğu görülmektedir $(r=0.788, p<0.01)$.

. "Oyun ve Gerçek Dünya Arasındaki Etkileşim" ve "Çevrimdışı Aktivizm" boyutları arasındaki ilişkinin de yüksek düzeyde olduğu görülmektedir $(r=0.617, p<0.01)$.

. "Oyun ve Gerçek Dünya Arasındaki Etkileşim" ve "Kimliklenme Süreci" boyutları arasındaki ilişki de güçlü bir ilişkidir ( $r=504, p<0.01)$.

. "Sosyal Etkileşim" ve "Kimliklenme Süreci" boyutları arasındaki ilişki de $r=0.662, p<0.01$ düzeyinde anlamlıdır.

- Aralarında en düşük düzeyde ilişki bulunan boyutlar ise "Çevrimdışı Aktivizm" ve "Kimliklenme Süreci" arasında $(r=0.334, p<0.01)$ ve 
"Çevrimdışı Aktivizm" ve "Sosyal Etkileşim" boyutları arasındadır $(r=0.470, p<0.01)$. Bununla birlikte bu düzeyde bir ilişki bile boyutlar arasında zayıf değil, orta düzeyde bir ilişki olduğunu göstermektedir. Analiz sonuçları ve çalışmanın varsayımlarına bakıldığında belirlenen boyutların tümünün arasında pozitif bir ilişki olduğu görülmektedir.

Çalışmada geliştirilen ölçeğin betimleyici faktör analizi yapılmış ve faktör analizi sonuçlarına göre faktörleşme istenilen düzeydedir ve çok yüksek güvenirlik katsayısına sahiptir. Faktörleşme hipotezleri doğrulama amaçlı belirlenen dört boyut ve o boyutlar için belirlenen sorular altında gerçekleşmiştir. Hipotezlerin doğrulanıp doğrulanmadığını anlama amaçlı yapılan Pearson Korelasyon Analizi, boyutlar arasındaki ilişkilerin niteliğine dair sonuçları vermektedir. Buna göre "Hipotez 1" doğrulanmıştır: MMOG oyun yapısı ve oyun esnasındaki buffing, kill assisting, eşlik etme gibi etkileşimler "oyunla özdeşleşme" yi pozitif yönde etkilemektedir. "Hipotez 2" doğrulanmıştır: MMOG oynamak ile oyuncular arasındaki sosyal etkileşim arasında pozitif bir ilişki vardır. Guild/takım ve genel sohbet vs. aracılığıyla kurulan sosyal etkileşim ile oyun topluluğu oluşumu arasında pozitif bir ilişki vardır. Oyun topluluğuyla güçlü bir şekilde özdeşleşen oyuncuların diğer oyuncularla uzun dönemli anlamlı ilişkiler kurmak, sohbet etmek ve onlara yardım etmek için daha güçlü arzuları ve ilgileri vardır. MMOG oyun topluluğu üyesi olan oyuncular büyük olasılıkla oyun dışında gerçek dünyada da buluşmaktadır. Dolayısıyla "Hipotez 3a, 3b ve 3c" doğrulanmıştır. Son boyutu ortaya koymak üzere önerilen hipotezler $4 a$ ve $4 b$ doğrulanmıştır. Yani; bir oyun topluluğu üyesi olmak oyunculara gerçek dünyada organize olma ve protestolara katılma, yardım toplama vb. gibi birlikte hareket etme yeteneği sağlamaktadır ve MMOG oyun toplulukları muhalif oldukları durumlarda büyük olasılıkla iktidar siyasalarına karşı direniş göstermekte ve protesto etmektedirler.

Pearson Korelasyon Analizi boyutlar arasındaki ilişkileri ve araştırma hipotezlerinin doğrulanıp doğrulanmadığına dair sonuçları vermektedir. Araştırma başında hipotezler doğrultusunda tasarlanan ve araştırma sorusunu cevaplaması beklenen süreç aşağıdaki şekilde kurgulanmıştır:

Şekil 1. Boyutlar Arasındaki Korelasyon Düzeyleri

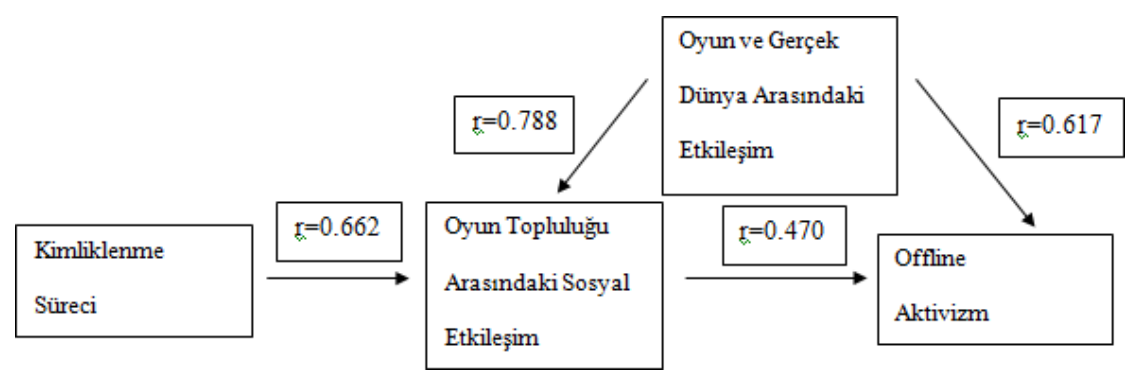


Boyutlar arasındaki korelasyon düzeyleri ve hipotezlerin doğrulanması, çalışmanın temeli olan araştırma sorusunun da yanıtını vermektedir. Buna göre; MMOG oyunlar karşı hegemonya alanı yapılandırmada ve oyun topluluklarının aktivizmi karşı hegemonya hareketlerinde etkilidir.

\section{Sonuç ve Öneriler}

Siyasal toplumsallaşmada son on yıla kadar büyük ölçüde geleneksel medya baskınken, artık bu anlamda gençler ve genç yetişkinlerin bilgisayar oyunlarından etkilendiği açıktır (Bevc, 2007, s. 26). Bu çalışmanın çıkış noktası dijital oyun oynayan bireylerin sanılanın aksine, toplumsal duyarlııkları yüksek vatandaşlar oldukları ve gerektiğinde kendi bireysel ya da toplumsal çıkarlarına karşı olan bir olayda oyun içi gruplaşma kanalları aracılığıyla bir araya gelerek seslerini duyuracakları ve çeşitli toplumsal hareketlere katılacakları varsayımı olmuştur. Dolayısıyla karşı hegemonya hareketleri için dijital oyun ve bu çalışma özelinde de MMOG'lerin etkili bir mecra olup olmadığına yönelik araştırma sorusuna yanıt aranmıştır.

Son yıllarda dünyada ve Türkiye'de yaşanan çeşitli hareketlerde internet üzerinden örgütlenen bireylere ve muhalif hareketlerin öne çıktığına şahit olunmuştur. Bu hareketlerde kuşkusuz en dikkat çeken nokta "asosyal" ya da "apolitik" olarak değerlendirilen, dijital oyun oynayan bireylerin söz konusu mücadelelerde yer alması ve "alanlara" inmesidir. Daha çok bir boş zaman ve eğlence etkinliği olarak algılanmasının aksine oyun oynama deneyimi oyun ortamında oyuncunun duyumları, düşünceleri, duyguları, davranışları ve anlam üretme süreçlerinden oluşan bir bütündür. Dolayısıyla oyuncular oyuna pasif olarak katılmazlar; oyunu aktif olarak inşa eder, yorumlar ve edindikleri tecrübelere dayanarak tepkiler verirler. Ayrıca yüz binlercesi aynı anda, aynı oyunu oynayan bu bireyler, bir yandan oyun oynarken, bir yandan da güncel siyasal, ekonomik ve toplumsal olaylarla ilgili oyun esnası sohbetleri gerçekleştirmekte; gerektiğinde bu olayları profillerine yansıtmakta ya da yardım organizasyonları düzenlemektedirler.

Milyonlarca oyuncunun bir ağ aracilığıyla birbirine bağıl olduğu bu ortamda, oyuncuların gündelik hayatlarına ya da toplumsal olaylara yönelik tartışmalar yapmaları, bilgi aktarmaları ve görüş bildirmeleri kaçınılmaz olmaktadır. Gerçek hayatta algılanan toplumsal sınırlar dahilinde hareket eden ve kimi zaman görüş bildiremeyen bireyler, zaman ve mekân anlamında sınılları ortadan kaldıran çevrimiçi iletişim ortamında, düşüncelerini hiç olmadığı kadar rahatlıkla ifade etmektedirler. MMOG oynayan bireyler kimliklenme sürecinde grupla özdeşleşmeyi deneyimlemekte; bu özdeşleşme beraberinde sosyal etkileşim, çevrimiçi dünya ve gerçek dünya arasındaki etkileşimi getirmektedir. Artık karşı hegemonya hareketleri yalnızca işçi sınıfına bağlı ve salt ekonomik temelli değerlendirilmemelidir ki bu çalışmanın sonuçları da bu varsayımı doğrular nitelikte sonuçlara ulaşmıştır. MMOG oyun grupları hegemonyaya meydan okuyan nitelikte örgütlenmeye olanak sağlayan yapılardır. Laclau ve Mouffe (2008, s. 21-22) da toplum içerisindeki her türlü "konsensüs hegemonik bir eklemlenmenin sonucudur ve konsensüsün tam olarak gerçekleşmesini engel- 
leyen bir dışarısı daima var olacaktır" demişlerdir. Bahsedilen "dışarısı" MMOG oyuncularının kendilerine ait gördükleri "çevrimiçi oyun grupları"nın ortamıdır, çünkü Gramsci (2007, s. 53)'ye göre kişisel hedefleri birbirinden ayrı çok sayıda bireyin, aynı amaçlara ulaşabilmek adına kaynaşmalarını sağlayan bir kültürel-toplumsal birliğin gerçekleşme intimali her zaman mevcuttur, çünkü hegemonya çok farklı toplumsal gruplar arasındaki gerilimin egemen olduğu bir alanı ifade etmektedir. Bu noktada oyuncuların talep ettikleri kendi "kamusal alanları"dır. Hegemonya alanını ifade eden iki farklı toplumsal grup olarak çevrimiçi oyun grupları ve iktidar yapıları arasındaki ayrım, özgürlükçü ve otoriter örgütlenmeler arasındaki ayrıma eşdeğerdir. Bir yanda merkezileşmiş hegemonik yapılar, diğer yanda herhangi bir toprak sınırı ve hiyerarşik düzenleri olmayan ve karşı hegemonya hareketlerinde bulunan küçük topluluklar olarak çevrimiçi oyun grupları vardır.

MMOG oyuncularının kimliklenme süreci ile başlayan katılımlarının, beraberinde grup iletişimini de getirmesi ve gerçek hayattaki iletişimi etkilemesi, pek çok farklı konuda olduğu gibi siyasal, ekonomik ve toplumsal konulara da bu sürecin yansımasına yol açmaktadır. Nitekim araştırma sonucu da bu durumu desteklemiş; kimliklenme sürecindeki grupla özdeşleşmenin beraberinde sosyal etkileşimi, bu sosyal etkileşimin gerçek dünyadaki iletişime yansımasını ve herhangi bir eyleme geçme durumunda birlikte hareket edebildiklerini göstermiştir. Bu yüzden dijital oyunlarda özellikle MMOG'lerde aynı anda sosyal etkileşim de söz konusudur ve oyuncular yalnızca oyuncu değil, aynı zamanda birer sosyal aktör haline gelmektedirler.

Gerçek dünya ile binişik bir oyun oynama etkinliği, sanal ortamları gerçek hayattaki sonuçlar göz önüne alındığında görece daha güvenli olan kamusal alana dönüştürmektedir (Hemminger, 2009, s. 132, 142). Deuze (2006, s. 65)'ün de belirttiği gibi kullanıcılar kendi alanlarını yeni medyanın inovatif kullanımı aracılığıyla talep etmektedirler. Bu yeni kamusal alan için olan mücadele, hegemonya taraflarının her ikisi için de geçerlidir. Oyuncular kendilerine özel ve dokunulmaz gördükleri kamusal alanlarına herhangi bir müdahale istememektedirler. Ne de olsa gerçek dünyanın tamamı toplumun geri kalanına aittir. Onlara ait, kimliklenme süreçlerinde çok etkili, gerçek dünyada yapamadıkları ya da olamadıkları kadar özgür olabildikleri çevrimiçi kamusal alanı korumak ve yalın tabirle "rahat bırakılmak" istemektedirler. Bu durum tam anlamıyla monitöryal vatandaş kavramına karşılık gelmektedir, çünkü monitöryal vatandaşlar ortamı tararlar (scan) ve kendi ortamlarına müdahale edilmesi durumunda harekete geçerler. Bir soruna yönelik yapılması gereken o an yapılır, devamlıı̆̆ pek görülmez. Bu durum aslında karşı hegemonya hareketlerinin neden hegemonya sahibi güçlere karşı, yeni bir hegemonik güç haline gelemediklerini açıklar: toplum genelinde hegemonyayı sürdüren kesim olmak belli bir sürekliliği ve devamlılığı gerektirmektedir. MMOG oyuncuları kendi kamusal alanları olarak gördükleri "alana" bir müdahale söz konusu olmadığı sürece herhangi bir faaliyette bulunmazlar. Bu noktada belki kendi alanlarına müdahale edilmediği sürece pasif bir durumda olmaları, direniş ve karşı hegemonya hareketleri bağlamında zayıflatıcı bir anlayış olarak değerlendirilebilir. 
Fakat özellikle yeni neslin sanal uzamı gerçek hayatın sınırlamalar ve kurallarından bağımsız olarak değerlendirdiği gerçeğinden uzaklaşmamak gerekmektedir. Sanal dünya, onların kamusal alanıdır. Gerçek dünyadaki kurallar onlar için geçerli değildir ve bu yüzden de onların dünyasına müdahale edildiği noktada iktidar sahiplerinin bu alana güç uygulama girişimleri hoşnutlukla karşılanmaz. İnternete erişim yasağı ya da sınırlandırmalar gibi onların alanına müdahale edilmediği sürece kendi oluşumları ile yetinebilirler. Bu, sınırları ve dengeleri çok kaygan bir zemindir, çünkü çalışma kapsamında yapılan anket sonuçlarının da gösterdiği üzere çok büyük bir kendi kendine örgütlenme ve çevrimiçi aktivizmin, çevrimdışı aktivizme dönüşme potansiyelini barındırmaktadır.

Anket verilerine uygulanan istatistiksel analizlerin yorumlamaları göstermiştir ki, MMOG'ler oyuncuları kendi kültürel pratiklerini geliştirmeye (grupla özdeşleşme-Hipotez 1), oyun grupları içinde kurallar temelinde bir arada var olmaya (oyunla özdeşleşme), kendi aralarında örgütlenmeye (sosyal etkileşim-Hipotez 2), eleştirel, düşünsel, stratejik tutum ve davranış gösterebilme yetilerini ortaya koymaya, kendi sosyal, kültürel ve siyasal duruşlarını göstermeye teşvik etmekte (oyun ve gerçek dünya arasındaki etkileşim-Hipotez 3); oyunlarda kurulan sanal topluluklar aracılığıyla aktif özneler olarak yeni bir direniş ve karşı hegemonya yaratmaya yönelik hareketlere dahil olmalarını (çevrimdışı aktivizm-Hipotez 4) sağlamaktadır. Bir sistem olarak internetin karakteri, iş birliği ve bilgi üretimine, bilginin oyuncular arasında paylaşılmasına, eşzamanlı olarak iletişim kurmalarına, toplumsal sistem içinde ülke ya da dünya çapındaki protestolara katılmalarına, kolektif değerler, pratikler, kimlikler, hedefler oluşturmalarına yardımcı olmaktadır. Tıpkı oyun topluluklarının kendi kendine örgütlenen sistemler olması gibi, protesto/direniş hareketleri de kendiliğinden oluşmaktadır. Bu yönüyle sivil toplumun da bir parçasıdırlar ve demokrasinin gerçek anlamda intiyaç duyduğu, iktidar güçlerinin dayattığı politik sistemde alternatif konu ve çıkarların oluşabilmesinin garantisidirler. MMOG'ler ve oyuncuları siber protestoların potansiyel fonksiyonlarının tümünü taşımaktadırlar: Toplumda gelişen olumlu/olumsuz tüm olayların yanı sıra, kendilerinin de toplum için ne anlam ifade ettikleri konusunda farkındalık sahibidirler. Gerektiği takdirde protesto eylemleri için mobilize olmaktadırlar. Çevrimdışı aktivizm için örgütlenme aracı olarak kendi oyun grubu ağlarını kullanmaktadırlar. Çevrimiçi aktivizm aracılığıyla esnasında çevrimdışı protestolara destek olmakta; çevrimiçi protestoları biçimlendirmektedirler. Oyun dünyasına ait jargonları aracılığıyla "muhalif" kodlar üretmekte (Bernstein, 2003, s. 142), çeşitli toplumsal olaylarda bu dili kendilerini savunmak ve karşı hegemonya hareketlerini örgütlemek için kullanmaktadırlar. Nihayetinde çevrimiçi oyun gruplarını yalnızca eğlence, kendini kaptırma, gündelik hayattan uzaklaşma amaçlı değil; direniş, sosyal mobilizasyon, sosyal adalet ve özgürlük amaçlı da kullanmaktadırlar. Nitekim Caillois (2001, s. 39)'a da göre "oyunlar genellikle hedeflerine ancak bir suç ortaklığı yankısını uyandırdıklarında ulaşırlar".

Kendi kuralları ve kendi dili olan yeni bir kamusal alan olarak MMOG ortamı, bireyler, toplum ve akademik çalışmalar için çok farklı mücadele ve fırsatları 
beraberinde getirmektedir. Dijital oyunları ve oyuncuları, "eğlence faktörü nedeniyle küçümsememek ve potansiyellerini iyi değerlendirmek gerekmektedir" (Bayraktutan, 2016, s. 378). Bununla birlikte oyunların gerçek dünyadaki sivil hareketlere katılmaya etkisini ortaya koyan daha fazla çalışma yapılmasına intiyaç vardır. Sanal ortamın ve oyunların neden olduğu muhtemel tehlikelere odaklanmak yerine, eğitsel süreçlerde elde edilebilecek fırsatlara odaklanılmalı, bu yeni kamusal alanın kültürün tüm yönleriyle anlaşılmasına katkıda bulunmak bundan sonra yapılacak çalışmaların hedefi olmalıdır. Artık çevrimiçi ortamların kullanıcılar için önemini anlamak ve pek çok insanın -ki özellikle genç neslin- çevrimiçi ortamı gündelik hayatlarına dahil ettiği gerçeğinin farkında olmak gerekmektedir. Bunun yanında oyun grupları kendi aralarında oluşturdukları sinerjik yapılanma ile mevcut hegemonyanın karşısında bir karşı hegemonya hareketi olma potansiyeline sahiptirler ve karşı hegemonya hareketleri demokratik toplumların olmazsa olmaz dinamiklerindendir. Toplumun bir kısmı için "yeni" olanın, yeni nesil için gündelik hayatın bir parçası olduğu gerçeğiyle yüzleşerek, "tehlikeden" koruma, denetleme ve yasaklama anlayışı yerine "bu sürece nasıl adapte olunur" ve "bu süreçten en iyi nasıl yararlanıı" gibi sorulara odaklanılmalıdır. Schindler (1999, s. 85)'in de vurguladığı gibi "yasaklamak ya da kontrol etmek yeterlilik değildir".

\section{Kaynakça}

Bakardjieva, M. (2003). "Virtual Togetherness: An Everyday-Life Perspective", Media, Culture \& Society. Cilt: 25, 291-313.

Barrett, M. (2004). Marx'tan Foucault'ya İdeoloji.İstanbul: Doruk Yayınları.

Bayraktutan, G. (2016). “Toplumsal Hareketleri ve Değişimi Dijital Oyunlar Üzerinden Düşünmek", Özgürleşmenin Yolları. Der. Erdal Dağtaş, 366-378, Ütopya Yayınevi: Ankara.

Bekhtina, V.J. (2002). "Psychological Research of MUD Gamers", Yayınlanmamış Diploma Tezi. Psychology Department, Moscow State Üniversitesi, Rusya.

Bernstein, B. (2003). Class, Codes and Control Volume 1 Theoretical Studies towards a Sociology of Language. Routledge: Londra ve New York.

Bevc, T. (2007). "Konstruktion von Politik und Gesellschaft in Computer-spieIen?", Computerspiele und Politik. (içinde), Ed. Tobias Bevc, Cilt 5, 25-55.

Bourdieu, P. (1998). Practical Reason: On The Theory of Action. Stanford University Press: Stanford, Kaliforniya.

Caillois, R. (2001). Man, Play and Games. Çev. Urbana ve Chicago: Meyer Barash, University of Illionis Press.

Cassell, J. ve Jenkins, H. (1998). "Chess For Girls?: Feminism and Computer Games", From Barbie to Mortal Combat: Gender and Computer Games. (içinde) (Ed.) Justine Cassell ve Henry Jenkins, s. 2-45, Cambridge, MA: MIT Press.

Castells, M. (2012). "Ağ Toplumunda İletişim, İktidar ve Karşı-Iktidar", Yeni Med- 
ya Üzerine. (içinde) çev. Tülin Sepetci, 14-45, Antalya: Akdeniz Üniversitesi Yayınları.

Chadha, M.; Avila, A. ve Gil de Zúñiga, H. (2012). "Listening In: Building a Profile of Podcast Users and Analyzing Their Political Participation", Journal of Information Technology \& Politics. 9: 388-401.

Deuze, M. (2007). Media Work.Polity Press, Digital Media and Society Series: BirleŞik Krallık.

Deuze, M. (2006). "Participation, Remediation, Bricolage: Considering Principal Components of a Digital Culture", The Information Society. 22(2): 63-75.

Downey, J. ve Fenton, N. (2003). "New Media, Counter Publicity and the Public Sphere", New Media \& Society. 5(2), 185-202.

Fleissner, P. ve Romano, V. (2007). Digitale Medien-Neue Möglichkeiten für Demokratie und Partizipation? Trafo: Berlin.

Frasca, G. (2003). "Simulation versus Narrative: Introduction to Ludology", Video Game Theory Reader.(içinde), M. J. P. Wolf ve B. Peron (Ed.) New York: Routledge, 221- 235.

Fromme, J. (2003). "Computer Games As A Part Of Children s Culture", The International Journal of Computer Game Research. Mayıs, Cilt: 3, Sayı: 1.

Fuchs, C. (2008). Internet and Society-Social Theory in the Information Age. Routledge: New York.

Gil de Zúñiga, H. ve Valenzuela, S. (2010). "Weak Ties, and Civic Engagement The Mediating Path to a Stronger Citizenship: Online and Offline Networks", Communication Research. XX (X), 1-25.

Gil de Zúñiga, H.; Veenstra, A. S.; Vraga, E. K.; Wang, M.; DeShano, C. L.; Perlmutter, D. D.; Shah, D. V. (2007). "Online and Offline Activism: Communication Mediation and Political Messaging Among Blog Readers", The Annual Convention of the Association for Education in Journalism and Mass Communication Bildiri Sunumu. Ağustos 9-12, 2007, Washington, DC.

Gramsci, A. (2011). Prison Notebooks Volume 1. Columbia University Press, ABD.

Gramsci, A. (2007). Hapishane Defterleri. Belge Yayınları: İstanbul.

Habermas, J. (1991). The Structural Transformation of The Public Sphere. MIT Press: Cambrdige.

Hemminger, E. (2009). The Mergence of Spaces Experiences of Reality in Digital Role- Playing Games. Edition Sigma: Almanya.

Huizinga, G. (1980). Homo Ludens: A Study of The Play-Element in Culture. Büyük Britanya: Redwood Burn Ltd. Trowbridge\&Esher. 
Joyce, M. C. (2010). "Introduction: How To Think About Digital Activism?", Digital Activism Decoded The New Mechanics of Change. Idebate Press: New York \& Amsterdam.

Klimecki, R. ve Willmott, H. (2011). "Hegemony", Key Concepts in Critical Management Studies. (içinde) Der. M. Tadajewski, P. Maclaran, E. Parsons, SAGE Publications, 130-134.

Küklich,, J. (2007). Online-Rollenspiele als Soziale Experimentierräume", Computerspiele und Politik. (içinde), Ed. Tobias Bevc, Band 5, 7-23.

Laclau, E. ve Mouffe, C. (2008). Hegemonya ve Sosyalist Strateji: Radikal Demokratik Bir Politikaya Doğru. İletişim Yayınları: İstanbul.

Mouffe, C. (2000). "Deliberative Democracy or Agonistic Pluralism?" Social Research. 66(3): 746-758.

Nunnally, J. C. (1978). Psychometric Theory. New York, NY: McGraw-Hill.

Papacharissi, Z. (2009). "The Citizen is The Message - Alternative Modes of Civic Engagement", Journalism and Citizenship New Agendas in Communication. (içinde) Ed. Zizi Papacharissi, 29-42, New York, NY: Routledge.

Rushkoff, D. (2003). “Open Source Democracy: How Çevrimiçi Communication Is Changing Offline Politics", Demos. http://www.demos.co.uk/files/OpenSourceDemocracy.pdf

Schindler, F. (1999). "Spielen und Reflektieren Search \& Play Plus-eine Datenbank für Computerspiele", Medien+Merziehung. Nr. 2, Nisan, 85-88.

Schudson, M. (1998). The Good Citizen - A History of American Civic Life. Martin Kessler Books, The Free Press: Londra.

Shah, D. V.; Cho, J.; Nah, S.; Gotlieb, M. R.; Hwang, H.; Lee, N.; Scholl, R. M. ve McLeod, D. M. (2007). "Campaign Ads, Online Messaging, and Participation: Extending The Communication Mediation Model", Journal of Communication. 57, 676-703.

Smith, A. (2011). "The Internet and Campaign 2010", Pew Internet \& American Life Project. Washington. http://www.pewinternet.org/files/oldmedia/Files/Reports/2011/Internet\%2 0and\%20Campaign\%202010.pdf

Steinkuhler, C. A. (2004). "Learning in Massively Multiplayer Online Games", 6. International Conference on Learning Sciences International Society of Learning Sciences, 1-38, Santa Monica, Kaliforniya.

Storey, J. (2009). Cultural Theory and Popular Culture: An Introduction. Pearson: Ingiltere.

Utz, S. (2000). "Social Information Processing in MUDs: The Development of Friendships in Virtual Worlds", Journal of Online Behavior. $1(1)$. 
Van Looy, J.; Courtois, C. ve De Vocht, M. (2010). "Player Identification in Online Games: Validation of a Scale for Measuring Identification in MMORPGs", Fun and Games. Eylül 20115-17, 126-134.

Yee, N. (2006). "The Demographics, Motivations and Derived Experiences of Users of Massively-Multiuser Online Graphical Environments", PRESENCE: Teleoperators and Virtual Environments.15, 309-329. 